\title{
SISTEM INFORMASI PEMESANAN MAKANAN DAN MINUMAN DENGAN MENGGUNAKAN CLIENT SERVER DI KURING TAMAN PALEM CAFÉ \& RESTO BERBASIS WEB
}

\author{
Sepsa Nur Rahman, M.Kom ${ }^{1)}$, Yesri Elva, M.Kom ${ }^{2)}$,Annisak Izzaty Jamhur, M.Kom. \\ ${ }^{1}$ Fakultas Ilmu Komputer, Universitas Putra Indonesia "YPTK" Padang. \\ email: penulis Sepsanurrahman@upiyptk.ac.id
}

\begin{abstract}
Abstrak
Saat ini dalam kegiatan pemesanan Kuring Taman Palem Cafe \& Resto masih menggunakan cara konvensional, keberadaan sistem yang digunakan selama ini belum dapat dijadikan sarana yang baik karena belum adanya suatu program komputer khusus seperti contoh proses pendataan, pemesanan, booking dan laporan terlebih dahulu dicatat secara manual dan disimpan dibuku besar hal ini menyebabkan terkadang adanya ketidakakuratan data saat akan dilakukan pendataan ulang dan juga tidak tersusun secara rapi. Tujuan penelitian ini adalah membuat sistem informasi pemesanan menu yang dapat mengelola data menu, data pengguna, data pemesanan dan data booking. Dalam penelitian ini peneliti menggunakan metode Prototype sebagai metode pengembangan dan permodelan menggunakan UML (Unified Model Language). Sedangkan pembuatan websitenya sendiri menggunakan bahasa pemrograman PHP dengan MySQL untuk pengolahan Database dan bahasa pemrograman Java untuk aplikasi android. Dengan adanya sistem informasi pemesanan menu ini, maka diharapkan dapat membatu KURING TAMAN PALEM CAFE \& RESTO dalam mengelola data pemesanan serta dapat menjadi sarana informasi dan promosi bagi perusahaan.
\end{abstract}

Keywords: Website, Client Server, SQL

\section{PENDAHULUAN}

Perkembangan ilmu pengetahuan dan teknologi yang sangat pesat telah banyak memberikan manfaat dalam kehidupan, diantaranya adalah komputer, internet, bahkan alat telekomunikasi yang semakin canggih. Dengan adanya ketiga elemen tersebut, manusia telah dipermudah dalam mengakses data, mengolah data, juga dalam berkomunikasi yang tidak lagi dibatasi oleh jarak dan waktu bahkan tempat yang jauh sekalipun..

Dengan meningkatnya perkembangan teknologi yang semakin tinggi, menuntut layanan yang semakin mudah, cepat dan praktis. Hal ini masih belum memiliki efisiensi pekerjaan jika hanya bergantung pada alat tulis dalam memenuhi tuntutan layanan yang mudah, cepat dan praktis tersebut. Pemakaian sistem pemesanan makanan dan minuman untuk memudahkan proses kerja dalam lingkungan Kuring
Taman Palem Cafe \& Resto, pada sisi konsumen memiliki beberapa fungsi yang akan membantu proses pemesanan menu.

$\begin{array}{rrr}\text { Pemakaian } & \text { sistem } & \text { pemesanan } \\ \text { makanan dan minuman } & \text { untuk }\end{array}$ memudahkan proses kerja dalam lingkungan cafe sehingga diharapkan dengan adanya sistem pemesanan makanan di Kuring Taman Palem Cafe \& Resto berbasis web dapat memudahkan proses pemesanan oleh pelanggan dan dapat meningkatkan pemasukan bagi Kuring Taman Palem Cafe \& Resto. Berdasarkan beberapa kendala dan uraian diatas, maka penulis dapat membuat judul "Sistem Informasi Pemesanan Makanan Dan Minuman Dengan Menggunakan Client Server Di Kuring Taman Palem Café \& Resto Berbasis Web"

\section{METODE PENELITIAN}
1. Survey Lapangan 
Survey lapangan dilakukan untuk melihat lebih dekat dan untuk mengetahui permasalahan sebenarnya yang terjadi.

2. Identifikasi Masalah

Dari hasil survey lapangan maka permasalahan yang dapat di rumuskan adalah "Sistem Informasi Pemesanan Makanan Dan Minuman Dengan Menggunakan Client Server Di Kuring Taman Palem Café \& Resto Berbasis Web" masalah maka ditentukan tujuan penelitian yang merupakan hasil akhir dari pemecahan masalah.

3. Mempelajari Literatur

Untuk memaksimalkan hasil penelitian ini maka dilakukan kajian literatur yang berkaitan dengan sistem pemesanan makanan.

4. Pengumpulan Data

Setelah permasalahan dirumuskan maka dilakukan pengumpulan data promosi dan pemasaran yang terdiri dari penelitian lapangan (field reseaarch), penelitian perpustakaan (library research) dan penelitian labaratorium (laboratory research).

5. Perancangan dan pembangunan Aplikasi

Pada tahap perancangan sistem yang perlu diperhatikan disini adalah penetuan sistem yang tepat untuk ditetapkan pada cafe pada tahap perancangan aplikasi akan dilakukan coding pada Bahasa pemograman berbasis Web PHP dan dilengkapi dengan DBMS MySQL.

6. Pengujian Aplikasi

Pada Tahap pengujian Aplikasi, Aplikasi pemesanan yang telah dibangun di uji dengan cara di hosting sehingga dapat di ujicoba akses konsumen.

7. Penarikan Kesimpulan

Pada akhir pembahasan dilakukan penarikan kesimpulan sebagai jawaban dari permasalahan bagaimana merancang aplikasi pemesanan

\section{A. Analisa Sistem yang Berjalan}

Berdasarkan wawancara bersama pemilik dari Kuring Taman Palem Cafe \& Resto bukittinggi . Saat ini pelayanan yang berada di Kuring Taman Palem Cafe \& Resto bukittinggi masih menggunakan cara konvensional, keberadaan sistem yang digunakan selama ini belum dapat dijadikan sarana yang baik karena masih menggunakan cara konvensional dan belum adanya suatu program komputer khusus contoh proses pendataan dan laporan terlebih dahulu dicatat secara manual dan disimpan dibuku besar hal ini menyebabkan ketidakakuratan data saat akan dilakukan pendataan ulang dan juga tidak tersusunrapi.

Untuk mendapatkan pemahaman terhadap aktifitas suatu sistem, maka diperlukan uraian beberapa aktifitas sistem yang berhubungan dengan sistem yang sedang berjalan digambarkan melalui flowchart sistem yang sedangberjalan.

\section{Identifikasi Masalah}

Masalah yang telah ditemukan dari hasil observasi maka dilakukan analisis permasalahan yaitu menentukan masing-masing masalah yang telah teridentifikasi.

\section{B. Perancangan Unified Modeling Language (UML)}


Unifed Modeling Language (UML) merupakan bahasa visual untuk permodelan dan komunikasi mengenai sebuah sistem dengan menggunakan diagram dan teks-teks pendukung, berikut adalah Unifed Modeling Language yang diusulkan:

\section{UsecaseDiagram}

Usecase adalah gambaran fungsionalitas dari suatu sistem, sehingga pengguna sistem paham dan mengerti mengenai kegunaan sistem yang akan dibangun, berikut adalah usecase diagram yang diusulkan :

\section{ClassDiagram}

Class diagram menggambarkan struktur dan deskripsi class, package dan objek yang saling terhubung. Class diagram yang dijelaskan pada analisa ini :

\section{Desain Sistem}

Desain Sistem merupakan kunci utama suksesnya sistem yang akan dirancang, karena perancangansecara detail akan dimuat semua rancangan yang akan mengarah pada teknik pelaksanaannya.

\section{Halaman Login}

Berikut adalah bentuk tampilan dari halaman login

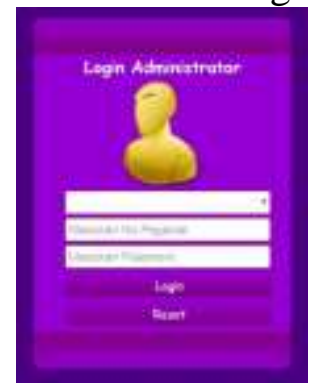

2. Halaman Utama

Berikut adalah bentuk tampilan dari halaman utama

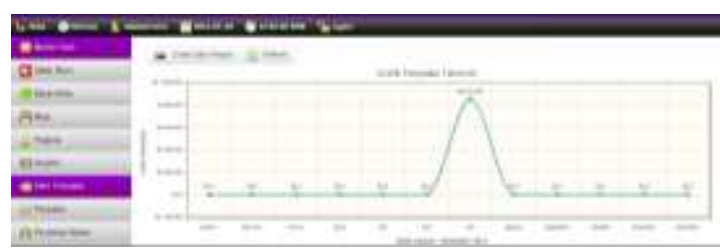

\section{Halaman Utama 2}

Berikut adalah tampilan dari halaman utama 2

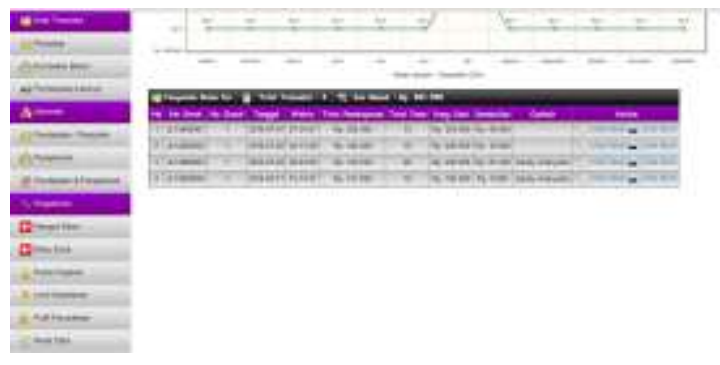

\section{Halaman Mod_Kasir}

Berikut adalah bentuk tampilan dari halaman Mod_Kasir

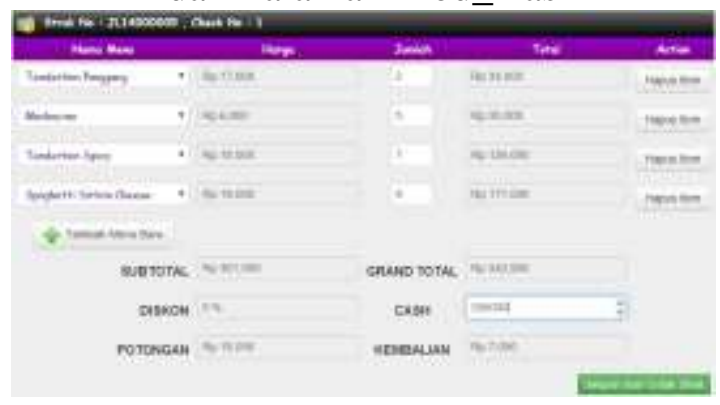

5. Halaman mod_kategori

Berikut adalah bentuk tampilan dari halaman Mod_kategori

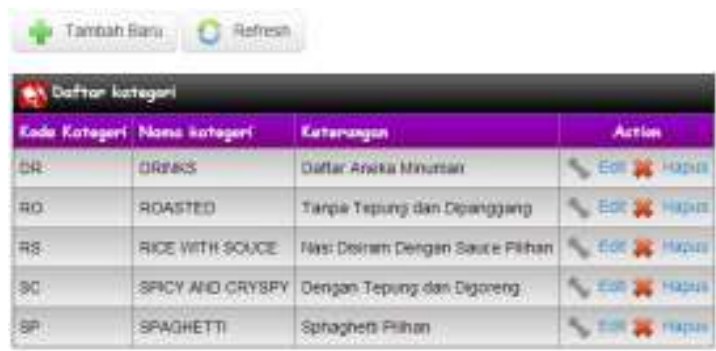

6. Halaman data meja 1

Berikut adalah bentuk tampilan dari halaman data meja 


\begin{tabular}{|c|c|c|c|c|c|}
\hline \multicolumn{6}{|c|}{ E Data Meja. } \\
\hline No mejas & Booking & Wobsu looking & $\operatorname{Tan}$ & Kapeita & Action \\
\hline Mega I & $x$ & - & - & 5 orang & S. Eee $\boldsymbol{\alpha}$ rops: \\
\hline Meja 2 & 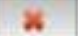 & - & - & 20 rang & $\checkmark$ Fde $\mathbf{\alpha}$ Hopeli \\
\hline Meja 1 & ж & - & - & 30 tang & S Ede Х rapus \\
\hline MeraT & $x$ & - & - & 13 oing & S Eded a Hapus \\
\hline
\end{tabular}

7. Halaman data meja2

Berikut adalah bentuk tampilan dari halaman data meja 2

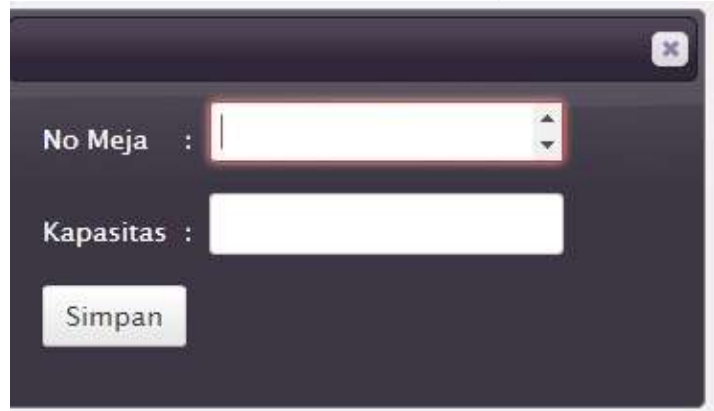

8. Halaman daftar menu 1

Berikut adalah bentuk tampilan dari halaman daftar menu 1

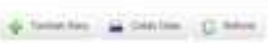

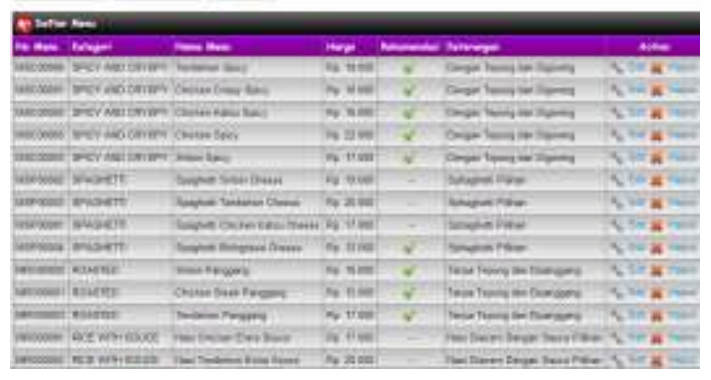

9. Halaman daftar menu 2

Berikut adalah bentuk tampilan dari halaman daftar menu 2

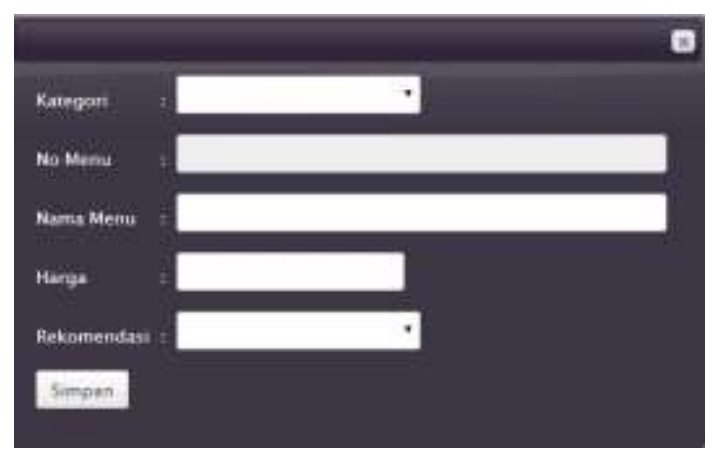

10. Halaman daftar level

Berikut adalah bentuk tampilan dari halaman daftar level

\begin{tabular}{|c|c|c|c|c|}
\hline \multicolumn{5}{|c|}{ J Daftar Level Pedas } \\
\hline No Level & Level Pedas & Hange & Jumlah Cabs & Action \\
\hline Loos & LEVEL 1 & Rp: 0 & 0 Buah & S. Edt os Rapus \\
\hline $\mathrm{L} 002$ & LEVEL 2 & $R p 0$ & 7 Buan & $\$$ Edit $\alpha$ rapus \\
\hline 4003 & LEVET 3. & Rp 0 & 2 Buan & Q Esti 2 ropus \\
\hline L004 & LEVEL 4 & Rp 0 & 3 Euah & S Edit w hapus \\
\hline 2005 & LEVEL 5 & Rp 1000 & 4 Buah & \$. Tan w Kapus \\
\hline 1006 & LEVEL 6 & $R p 2000$ & 5 Buah & $\$$ Edit os naput \\
\hline
\end{tabular}

\section{SIMPULAN}

Dari hasil penelitian yang dilakukan, maka dapat diambil kesimpulan yaitu Sistem Informasi Pemesanan Makanan dan Minuman dengan menggunakan client server dengan menggunakan WEB sebagai berikut, Sistem yang dibangun ini menggunakan model Web Service sebagai untuk pelayan dengan website sebagai pengolah data, Sistem yang dibangun ini juga dapat mempermudah dalam melakukan transaksi pemesanan makanan dan menu sesuai dengan website, Sistem ini juga dapat mempermudah dalam melakukan transaksi booking, Sistem aplikasi ini layak untuk digunakan sebagai aplikasi yang dapat memesan makanan dan melakukan booking tempat.

\section{UCAPAN TERIMAKASIH}

Berisi ucapan terima kasih kepada lembaga pemberi dana/individu, dan atau yang telah membantu dalam pelaksanaan penelitian dan penulisan manuskrip serta lembaga afiliasi penulis. [Times New Roman, 12, normal], spasi 1.

\section{DAFTAR PUSTAKA}

A Rosa S dan Shalahuddin M. 2014. Rekayasa Perangkat Lunak Terstruktur dan Beroientasi Objek. Bandung : Informatika. 
Hanif Al Fatta. 2007. Analisis dan Perancanagan Sistem Informasi untuk Keunggulan Bersaing Perusahaan dan Organisasi Modern. Yogyakarta: Andi.

Hartono, Bambang., "Sistem Informasi Manajemen Berbasis Komputer"., Jakarta: Rineka Cipta., hal.15-20, 2013.

Hidayatullah, Priyanto, dan Jauhari "Pemrograman Web"., Bandung : Penerbit Informatika Bandung., 2014.

Jogiyanto, MH. 2008. Analisis dan Desain Sistem Informasi. Yogyakarta : Andi.

Kotler, Philip. 1999. Kotler on

Marketing: How to Create, Win, and Dominate Markets. New York, NY: Free Press.

Nugroho, Eko., "Sistem Informasi Manajemen: Konsep Aplikasi dan Perkembangnya", Yogyakarta: Penerbit ANDI, hal. 16-142, 2010.

Pressman Roger S. 2012. Rekayasa Perangkat Lunak - Buku Satu, Pendekatan Praktisi (Edisi 7). diterjemahkan oleh : Adi Nugroho, et al. Yoyakarta: Andi.

Siagian, Sondang P., "Sistem Informasi Manajemen"., Jakarta: PT Bumi Aksara., hal.22, 2014.

Sutabri Tata. 2012. Konsep Sistem Informasi. Yogyakarta : Andi.

Saputra, Dony. dkk., "Rancang Bangun Sistem Informasi Manajemen Restoran"., Tanggerang : STMIK Rahaja. 2015 